\title{
An Integrative Review on the Research on the Impact of Teacher Inquiry on Student Achievement
}

\author{
Hana Turner-Adams ${ }^{a}$, Aaron Wilson ${ }^{b}$, and Rebecca Jesson ${ }^{b}$ \\ aschool of Education at Auckland University of Technology \\ ${ }^{b}$ Woolf Fisher Research Centre, Faculty of Education and Social Work, University of Auckland
}

This review investigated the impact of teacher inquiry on student achievement and identified characteristics of effective inquiry. We first explore the theoretical underpinning inquiry research and then discuss studies that demonstrated an association between an inquiry-and student achievement shifts. Effective teacher inquiries had a focus on student achievement, sufficient time, teacher engagement and collaboration, external expertise, and leaders' support. When the aspects above were present, the potential for the intervention to demonstrate positive shifts in student achievement increased. Barriers to effective inquiry are also suggested. The review concludes with implications and recommendations for future research studies.

Keywords: Teacher inquiry, Practitioner research, Action research, Teacher professional development, Student achievement

\section{Introduction and context}

The aim of this literature review was to investigate the impact of teacher inquiry on student achievement both in New Zealand and internationally, and to identify the characteristics of effective and non-effective teacher inquiries. Since the introduction of the 'teaching as inquiry' (TAI) model in the New Zealand Curriculum (NZC; Ministry of Education, 2007), teachers have been expected to inquire into the impact of their teaching on student outcomes and to refine their practice accordingly. The aim of TAl is more effective teaching and improved student outcomes. Teacher inquiry involves educators undertaking evidence-based investigations into their professional practice in a way that is "systematic, intentional and selfcritical" (Cochran-Smith \& Lytle, 1999, p. 22). Inquiry differs from teacher reflection where teachers think about their work and how they could improve their practice, but not in a way that is regular, methodical, or intentional (Cochran-Smith \& Lytle, 1999).

Many schools in New Zealand have adopted inquiry-based professional learning and development (PLD) and have connected teachers' inquiries to appraisal. However, the New Zealand teachers' unions recently negotiated an accord with the Ministry of Education to remove performance appraisal of teachers (Ministry of Education, 2019), which may change how schools approach PLD in the future.

Aligning inquiry with teacher proficiency has potentially shifted the focus from improved educational outcomes for students to benefits for other stakeholders instead. It may also limit teacher risk-taking. However, if professional learning and shifts in practice are the focus of teacher observation, rather than appraisal, then teachers may feel more confident to take risks and attempt more challenging inquiries. 


\section{Theoretical teacher inquiry models}

This section contextualises the teacher inquiry field by discussing theoretical models utilised by researchers in this literature review. Teacher inquiry models are usually cyclical and ongoing. Each model typically includes: (1) a problem-identification or goal-setting phase; (2) a learning-needs identification phase; (3) an intervention or implementation phase where teachers alter their practice to effect change; and (4) an evaluative stage where teachers assess the effectiveness of their intervention on student progress or achievement, usually through collecting, analysing, and interpreting data. Following the evaluation, teachers use findings from the data to decide the students' next learning steps (and the inquiry cycle begins again). Four theoretical models of teacher inquiry - teaching as inquiry, professional inquiry, action research, and collaborative inquiry - are discussed further below.

\section{Teaching as inquiry (TAI)}

The TAI model emerged from the Social Sciences Tikanga-a-iwi Best Evidence Synthesis (Aitken \& Sinnema, 2008). A draft from the best evidence synthesis (Aitken \& Sinnema, 2008) was reproduced in the NZC document (Ministry of Education, 2007). The NZC states that "effective pedagogy requires that teachers inquire into the impact of their teaching on their students" (p. 35).

TAl is a four-phase recursive cycle comprising the focusing review, teaching inquiry, teaching and learning, and the learning inquiry. In the focusing inquiry, teachers determine students' prior knowledge by accessing different sources of evidence. Teachers then prioritise what students need to learn and set learning goals. In the teaching inquiry, teachers identify the knowledge and learning they need to help students achieve. Teachers may refer to research-based evidence, access PD, and collaborate with colleagues to plan learning experiences. During the teaching and learning phase, teachers purposefully change their practice and implement learning experiences, and in the learning inquiry, the teacher evaluates whether their adapted teaching or intervention resulted in improvements for student learning. Data are collected, analysed, and interpreted, and guide teachers' decisions on the students' next learning steps, and then the inquiry cycle begins again (Aitken \& Sinnema, 2008).

\section{Professional inquiry}

Timperley, Parr, and Bertanees' (2009) model of 'professional inquiry' evolved Donovan, Bransford, and Pellegrino's (1999) theory of how people learn. Professional inquiry is a knowledge-building cycle, designed to develop self-regulatory and co-regulatory learning. Similar to the TAI model (Aitken \& Sinnema, 2008), parts 1 and 2 involve identifying the students' and teacher's learning needs.

In part 2 of 'professional inquiry' (Timperley et al., 2009), teachers are challenged to reflect on how they contributed to their students' current outcomes and identify strategies to meet students' learning needs. Recognising one's own teaching development needs is difficult to do in isolation; therefore, Timperley et al. (2009) maintained that the teachers' learning inquiry should be collective and collaborative.

The next stage of professional inquiry involved teachers' engagement with external expertise to increase and extend their pedagogical knowledge and teaching skills. Specialist expertise is needed to support the in-depth learning required to facilitate change. Then 
teachers use their improved knowledge and skills to make changes to their teaching (Timperley et al., 2009).

The final phase of the model requires teachers to assess the impact of practice changes on student outcomes. Depending on what the student data or other evidence reveals, teachers may revise and adjust their goals. Similar to TAI (Aitken \& Sinnema, 2008), the professional inquiry model cycles back to the students' learning needs phase to re-assess progress and further advance student learning.

\section{Action research}

Action research originated as a methodology in the 1950s (Corey, 1954) and involves a recursive cycle where a problem is identified, a hypothesis framed, goals set, actions followed, and then results are recorded. Typically, the action research field refers to research that teachers undertake independently into their own practice (e.g., see Corey, 1954; Lerman \& Zehetmeier, 2008; Nolen \& Putten, 2007).

\section{Collaborative inquiry}

Collaborative inquiry is similar to action research, but the collaboration aspect requires that teachers work together. Earl, Timperley, and Stewart (2008) defined collaborative inquiry as "a systematic process for learning in which a group works together in repeated episodes of reflection and action to examine and learn about an issue that is of importance to them" (p. 11). Collaboration is referred to within other models of inquiry (e.g., see Timperley et al., 2009), but it is not specified how teachers should work together, the level of collaboration, or where in the inquiry cycle collaboration should occur (Limbrick \& Knight, 2005).

Butler and Schnellert (2012) identified five criteria for measuring teacher collaboration. Level 0 is where no teacher collaboration took place. At Level 1, collaboration is low-level; teachers may share the assessment of students' work, but do not plan work together or have shared goals. Teachers who collaborate at Level 2 are at the consultative information-sharing stage. These teachers have some shared goals, resources and ideas, but there is no collaborative planning, or monitoring of each other's teaching or inquiry goals.

Teachers who collaborate at Level 3 have common goals as a basis for co-planning. Resources and ideas are shared, and co-teaching is aligned with teachers' shared goals. Some checking of each other's teaching occurs, but a long-term focus or evaluation of goals is not apparent. At level 4, teachers share goals, co-plan, co-teach, and work together to implement practices related to meeting their shared goals. Teachers debrief after lessons and discuss the effectiveness of teaching strategies. Some co-reflection and problem-solving takes place, and inquiries are longitudinal and situated within a practice-based inquiry cycle (Butler \& Schnellert, 2012, p. 1218).

Level 5 collaboration involves an established shared inquiry into teacher practice and learning (Butler \& Schnellert, 2012, p. 1218). Teachers have common goals for students and share professional learning goals with their inquiry partner(s). Co-planning is connected to shared goals and co-teaching focuses on implementing, critiquing, and improving teaching practices. Co-reflection and problem-solving is ongoing and positioned within a longitudinal inquiry cycle (Butler \& Schnellert, 2012). 


\section{The current review}

Although much of the existing teacher inquiry literature concentrates on non-achievement outcomes (e.g., student participation, engagement, critical thinking, behaviour, values, and enjoyment of learning) or outcomes for teachers or other stakeholders, the focus of this integrative literature review was research which provided evidence of shifts in student achievement. Timperley, Wilson, Barrar, and Fung's (2008) review captured much of the relevant literature related to teacher PD approaches associated with improvements in student learning up until 2007. The current review, therefore, concentrated on research published from 2008 onwards. Additionally, we discuss the characteristics of effective and inquiry projects that are identified in the literature. Effective inquiry projects were typified by a focus on student achievement, sufficient time, teacher engagement and collaboration, external expertise, and school leaders' support. Conversely, the barriers to effective inquiry included teachers' limited data literacy, a lack of clarity about the impact of an inquiry on student achievement, and where changes to teacher practice were insufficient.

\section{Method}

\section{Search and selection procedure}

Four databases and search engines (ProQuest Education, PsychINFO, ERIC, and Google Scholar) were used to locate relevant literature. Specific keywords (e.g., 'teacher inquiry', 'teacher research', 'teacher collaboration' and 'teacher PD' combined with 'student achievement' or 'student outcomes' or 'student attainment') were used to search document abstracts. Filters were set to include only documents published in English after December 2007 and where the full text was available. Although a systematic approach was followed to locate research, this is an integrative review. A systematic review analyses data from the reviewed studies, and an integrative review synthesises literature related to a specific topic.

The initial searches and checking of abstracts based on the inclusion and exclusion criteria stated below produced an initial set of 91 studies. The removal of duplicates and reading of the full texts identified further studies that did not meet the inclusion criteria. Therefore, a further 78 studies were removed. A final set of 13 studies remained, which are displayed and summarised in Table 1.

\section{Inclusion criteria}

1. Inquiry-related research studies undertaken by teachers in primary (elementary) or secondary schools and focused on raising or improving student achievement.

2. Studies where teachers used an inquiry model to investigate and research a problem or challenge within their school or teaching practice.

3. Research studies that provided evidence of shifts in student achievement.

\section{Exclusion criteria}

1. Research studies that focused on students' inquiry projects in classrooms or 'inquirybased' learning. 
2. 'Inquiry-based teaching' or 'inquiry-based instruction' research, where the focus was on teaching students through inquiry.

3. Inquiry research by non-teaching staff in schools (e.g., school counsellors).

4. Inquiry research in early childhood education.

5. Post-secondary or university-level inquiry research, pre-service teachers or initial teacher education.

6. Studies that did not include data or evidence to substantiate claims of improved student achievement.

\section{Teacher Inquiry and Student Achievement}

Overall, only a small number of teacher inquiry research studies published in New Zealand and internationally since 2008 have had a student achievement focus or have provided evidence to support claims of achievement shifts. Despite an abundance of teacher inquiry research, many studies in the field were descriptive or reported non-achievement related benefits (Guskey \& Yoon, 2009; Kennedy, 1998; Yoon, Duncan, Lee, Scarloss, \& Shapley, 2007). The 13 studies discussed in this section are displayed in Table 1. As inquiry projects conducted by teachers are not usually published, most evidence in the literature comprises studies that featured inquiries rather than the inquiries themselves. Furthermore, where inquiry is one part of a multi-component programme, it is not always possible to disambiguate inquiry effects from other aspects of the project to identify what led to the reported shifts in achievement. However, the 'method' of the inquiry process does interact with the content being learned and implemented, and therefore, it is suggested that the use of an inquiry approach contributed to an appropriate focus being adopted. 
Table 1.

A Summary of the Teacher Inquiry Research that Reported Student Achievement Outcomes

\begin{tabular}{|c|c|c|c|c|c|c|}
\hline & Author(s) & Country & Age/grade level & Sample size & Area of Inquiry & Outcomes of Inquiry \\
\hline 1. & $\begin{array}{l}\text { Bruce, Esmonde, } \\
\text { Ross, Dookie, and } \\
\text { Beatty (2010) }\end{array}$ & Canada & $\begin{array}{l}\text { Kindergarten to Year } \\
6 \text { ( } 4-12 \text { years) }\end{array}$ & $\begin{array}{l}88 \text { teachers from two } \\
\text { school districts }\end{array}$ & Mathematics & $\begin{array}{l}\text { Increased achievement in groups where students' } \\
\text { teachers participated in collaborative inquiry. }\end{array}$ \\
\hline 2. & $\begin{array}{l}\text { Buczynski and } \\
\text { Hansen (2010) }\end{array}$ & USA & $\begin{array}{l}4^{\text {th }}-6^{\text {th }} \text { grade (but } \\
\text { achievement tests } \\
\text { only administered to } \\
5^{\text {th }} \text {-grade students) }\end{array}$ & $\begin{array}{l}118 \text { participating teachers } \\
\text { matched with similar non- } \\
\text { participant teachers } \\
729 \text { students (treatment) } \\
1235 \text { students (control) }\end{array}$ & Science & $\begin{array}{l}\text { District One science test scores improved marginally } \\
\text { for students of Inquiry learning partnership (ILP) - } \\
\text { participating teachers compared with non-ILP } \\
\text { teachers. For District Two, proficiency scores for ILP } \\
\text { teachers' students remained at } 30 \% \text {. Non-ILP } \\
\text { teachers' students showed a } 4 \% \text { reduction in } \\
\text { proficiency scores. }\end{array}$ \\
\hline 3. & Earl et al.(2008) & $N Z$ & $\begin{array}{l}\text { Grade level not } \\
\text { stated. }\end{array}$ & 75 teachers & Cross-curricular & $\begin{array}{l}\text { Most teachers reported positive shifts in Māori and } \\
\text { Pacific Islands students' achievement outcomes }\end{array}$ \\
\hline 4. & $\begin{array}{l}\text { Ell and Meissel } \\
\text { (2011) }\end{array}$ & NZ & $\begin{array}{l}\text { Year 4-6, Primary } \\
\text { school }\end{array}$ & $\begin{array}{l}5 \text { schools (A, B, C, D, \& E); } \\
256 \text { students; } 36 \text { teachers }\end{array}$ & Mathematics & $\begin{array}{l}\text { Accelerated progress in mathematics in all schools } \\
\text { except one. Results varied by score. }\end{array}$ \\
\hline 5. & $\begin{array}{l}\text { Gersten, Dimino, } \\
\text { Jayanthi, Kim, and } \\
\text { Santoro (2010) }\end{array}$ & USA & First Grade & $\begin{array}{l}19 \text { schools ( } 10 \\
\text { intervention; } 9 \text { control) } \\
39 \text { teachers in the teacher } \\
\text { study group; } 42 \text { in the } \\
\text { control group }\end{array}$ & Reading & $\begin{array}{l}\text { No significant impact on the post-test Woodcock } \\
\text { Diagnostic Reading Battery measures of Reading } \\
\text { Vocabulary and Passage Comprehension. Moderately } \\
\text { large effect size for Oral Vocabulary }(d=0.44 ; p<.10) \\
\text { was marginally significant. The effect size for Oral } \\
\text { Vocabulary was double the impact on the Reading } \\
\text { Vocabulary subtest of } 0.21 \text {. }\end{array}$ \\
\hline
\end{tabular}




\begin{tabular}{|c|c|c|c|c|c|c|}
\hline & Author(s) & Country & Age/grade level & Sample size & Area of Inquiry & Outcomes of Inquiry \\
\hline 6. & $\begin{array}{l}\text { Knight, Kirton, and } \\
\text { McCaulay (2008) }\end{array}$ & NZ & $\begin{array}{l}\text { Years 4-8 (Grades 3- } \\
\text { 9) }\end{array}$ & $\begin{array}{l}13 \text { schools in South } \\
\text { Auckland, NZ }\end{array}$ & $\begin{array}{l}\text { Reading and } \\
\text { writing }\end{array}$ & $\begin{array}{l}\text { After three years, reading achievement improved } \\
\text { from a below-average band mean reading stanine } \\
\text { (STAR) of } 3.21 \text { to an average stanine of } 4.00 \text {. Median } \\
\text { writing levels increased at a higher rate than } \\
\text { maturational gains. }\end{array}$ \\
\hline 7. & $\begin{array}{l}\text { Limbrick, } \\
\text { Buchanan, } \\
\text { Goodwin, and } \\
\text { Schwarcz (2010) }\end{array}$ & $\mathrm{NZ}$ & Primary school & $\begin{array}{l}20 \text { teachers from six low- } \\
\text { decile schools }\end{array}$ & Writing & $\begin{array}{l}\text { In years } 1 \text { and } 2 \text {, mean raw score gains in e-asTTle } \\
\text { writing (from baseline) were } 56 \text { and } 61 \text {, which was } \\
\text { double the expected rate of progress. Expected mean } \\
\text { gain over a year }=27 \text { points. }\end{array}$ \\
\hline 8. & Mykysey (2011) & USA & $\begin{array}{l}1^{\text {st }} \text {-grade emergent } \\
\text { bilingual students }\end{array}$ & Six students & $\begin{array}{l}\text { Spelling and } \\
\text { writing (in } \\
\text { English) }\end{array}$ & $\begin{array}{l}\text { Over six months, all students progressed in writing } \\
\text { and spelling. }\end{array}$ \\
\hline 9. & $\begin{array}{l}\text { Nichol, Chow, and } \\
\text { Furtwengler } \\
\text { (2018) }\end{array}$ & USA & $5^{\text {th }}$-grade students & $\begin{array}{l}N=876 \text { ( } 50 \% \text { female; } 50 \% \\
\text { male) }\end{array}$ & Science & $\begin{array}{l}\text { Immediately following the intervention, little or no } \\
\text { effect on achievement was evident for treatment } \\
\text { teachers' students. One year after the programme, } \\
\text { treatment group students significantly ( } p<.001) \text { out- } \\
\text { performed comparison group students, with a } \\
\text { medium effect size of } \eta^{2}=0.088 \text {. }\end{array}$ \\
\hline 10. & $\begin{array}{l}\text { Parr and Timperley } \\
\text { (2010) }\end{array}$ & $\mathrm{NZ}$ & $\begin{array}{l}\text { Primary schools, Year } \\
\text { 1-8 but data } \\
\text { collected from Year } \\
3-8\end{array}$ & $\begin{array}{l}\text { Schools }=91,127 \text { and } 84 \\
\text { for cohort } 1,2 \text { and } 3 \\
\text { respectively } \\
\text { Student Reading sample: } \\
9350 \text { across three cohorts. } \\
\text { Student writing sample: } \\
7403 \text { across three cohorts }\end{array}$ & $\begin{array}{l}\text { Reading and } \\
\text { writing }\end{array}$ & $\begin{array}{l}\text { In writing achievement, effect size gains for the three } \\
\text { cohorts were } 0.79,0.62 \text {, and } 0.88 \text {, respectively. The } \\
\text { gain for the lowest } 20 \% \text { of students was } 5-6 \text { times } \\
\text { higher than expected (effect size gains of } 1.81,1.93 \\
\text { and } 2.07 \text { ). } \\
\text { In reading, effect size gains for the three cohorts } \\
\text { were } 0.28,0.28 \text { and } 0.44 \text {, respectively. Again, gains } \\
\text { for the lowest } 20 \% \text { of students were around } 2-3 \text { times } \\
\text { higher than expected. }\end{array}$ \\
\hline
\end{tabular}




\begin{tabular}{|c|c|c|c|c|c|c|}
\hline & Author(s) & Country & Age/grade level & Sample size & Area of Inquiry & Outcomes of Inquiry \\
\hline 11. & $\begin{array}{l}\text { Ronfeldt, Farmer, } \\
\text { McQueen, and } \\
\text { Grissom (2015) }\end{array}$ & USA & $\begin{array}{l}\text { Elementary and } \\
\text { secondary school }\end{array}$ & $\begin{array}{l}36 \text { schools and } 7,881 \\
\text { teachers for reading } \\
\text { models ( } 6,682 \text { for math) }\end{array}$ & $\begin{array}{l}\text { Reading and } \\
\text { mathematics }\end{array}$ & $\begin{array}{l}\text { Collaboration appeared to contribute to both student } \\
\text { achievement and teacher improvement. } \\
\text { Collaboration about student assessment appeared } \\
\text { more predictive of student achievement than } \\
\text { collaboration about instruction and students. }\end{array}$ \\
\hline 12. & $\begin{array}{l}\text { See, Gorard, and } \\
\text { Siddiqui (2016) }\end{array}$ & UK & $\begin{array}{l}\text { Year 2-6 students } \\
\text { aged } 6-11\end{array}$ & Nine primary schools & $\begin{array}{l}\text { Using enhanced } \\
\text { feedback to } \\
\text { enhance student } \\
\text { learning and } \\
\text { achievement }\end{array}$ & $\begin{array}{l}\text { Overall, the impact of the feedback intervention on } \\
\text { student achievement outcomes was not convincing. } \\
\text { The intervention students had lower gains in reading } \\
\text { ( } g=-0.04) \text { and writing }(g=-0.05) \text { but slightly higher } \\
\text { gains for mathematics }(g=+0.05) \text { than non- } \\
\text { intervention students. }\end{array}$ \\
\hline 13. & $\begin{array}{l}\text { Timperley, Parr, } \\
\text { and Bertanees } \\
(2009)\end{array}$ & NZ & Primary school & One case study school & Writing & $\begin{array}{l}\text { Effect size gain of } d=1.03 \text { in writing, which was more } \\
\text { than two times the expected gain in one year. }\end{array}$ \\
\hline
\end{tabular}


The research studies in this section reported students' achievement shifts using a range of evidence. Some studies reported effect sizes (Gersten et al., 2010; Nichol, Chow, \& Furtwengler, 2018; Timperley et al., 2009), whereas other studies described qualitative data, test results, or teacher/student artefacts (Earl et al., 2008). Although most studies discussed in this section showed positive shifts in student achievement, some achievement shifts were marginal (Nichol et al., 2018; See, Gorard, \& Siddiqui, 2016) or the achievement shifts did not occur where intended (Gersten et al., 2010). Since studies reported different types of effect size, the relative magnitude of each kind of effect is displayed in Table 2 for clarity.

Table 2

Types of Effect Sizes and Relative Magnitude

\begin{tabular}{lccc}
\hline & Cohen's $d$ and Hedges' $g$ & Eta Squared & Cliff's Delta \\
\hline Small & 0.2 & 0.02 & 0.147 \\
Medium & 0.5 & 0.13 & 0.33 \\
Large & 0.8 & 0.26 & 0.474 \\
\hline
\end{tabular}

(Refs: Becker, 2000; Ell \& Meissel, 2011)

\section{Inquiry research studies with medium-to-large effect size}

This section discusses four research studies where medium to large effect sizes were reported (Ell \& Meissel, 2011; Limbrick et al., 2010; Parr \& Timperley, 2010; Timperley et al., 2009). In Timperley et al. (2009), two cohorts of New Zealand primary schools (91 in cohort 1 and 218 in cohort 2) opted into a PD programme focused on improving student outcomes in either reading comprehension or writing. Achievement data were collected at the beginning of the project and at the end of years one and two.

One school was selected as a case study to illustrate a teacher inquiry cycle. In the first step of the school's inquiry (inquiring into students' learning needs), writing achievement was found to be below national levels. Teachers were motivated to engage with solving this problem, which led to the second phase, the inquiry into teachers' learning needs.

In the learning needs inquiry, teachers identified what they needed to learn to improve student achievement. Classroom observations revealed that teachers spent more time motivating students to write than teaching writing skills. Moreover, students had insufficient time to write, and most feedback they received was non-specific praise. Teachers next identified how their teaching had contributed to the students' current learning outcomes. They recognised two consequences: the students' low writing achievement and students' limited understanding of their learning. From these insights, teachers acknowledged they needed to learn more about teaching students how to write.

In the next step, 'deepening professional learning', teachers engaged with research and participated in structured classroom observations and feedback. Students were reinterviewed about their learning to test the effectiveness of teachers' changed practices but were found to still be confused about lesson objectives. Consequently, teachers worked on even more explicit instruction. A subsequent check found that students were able to articulate the lesson learning intentions and success criteria. 
Interrogation of student achievement data assisted teachers to focus their support efforts, and data discussions provided the impetus for a shorter assessment cycle so they could assess if practice changes made a difference. At the end of four months, students' writing showed significant gains. The overall effect size gain was $d=1.03$, which is more than twice the expected gain over one year.

In a connected study, Parr and Timperley (2010) explored a collaborative professional learning inquiry in three cohorts of schools focused on: raising student achievement, improving teacher content knowledge, transfer of pedagogy to practice, and leading professional learning communities. Over two years, there were considerable gains in writing achievement in each cohort of schools with effect sizes of $0.79,0.62$, and 0.88 , respectively. Gains for students who achieved in the lowest 20 percent in each cohort were 5-6 times higher than expected, with an average effect size gain of 1.94 .

In reading, the effect size gains for all cohorts over and above expected gains were $0.28,0.28$ and 0.44 , respectively. Gains for students who achieved in the lowest 20 percent were around two to three times higher than expected. Both studies reported extensive support from external expertise and a whole school focus to ensure consistency.

Limbrick et al.'s (2010) study of teacher inquiry in six low-decile primary schools focused on improving teacher knowledge and pedagogy in writing and raising writing achievement. Baseline data showed low achievement across all classes and schools. Data collected after the first and second year of the intervention showed mean raw score gains in e-asTTle writing of 56 and 61 respectively, which was double the expected rate of achievement of 27 points. Some classes' achievement gains were three times greater than expected. There were also statistically significant differences in both years between data collection points 1 and 2. Effect sizes were $d=0.45 ; p<0.001$ and $d=0.62 ; p<0.001$ for the first and second year respectively for almost all year groups.

Ell and Meissel's (2011) research into a collaborative inquiry took place in a cluster of 5 rural New Zealand schools (referred to as A, B, C, D, and E). During the inquiry, teacher action plans were collected and analysed, and mathematics achievement data were collected twice per term for three terms.

The maths progress of the students at each of the schools is presented in Table 3. A Cliff's delta above 0.147 represents progress above that expected from good teaching for the period of the study (see Table 2 for a further explanation of the magnitude of Cliff's delta effects). Accelerated progress was evident in multiplication/division and place value tasks, in all schools except one. Evaluation of teachers' action plans revealed that schools A, B and C focused mainly on students' test mastery and the knowledge it contained so they could identify students' gaps. School D, which had the highest achievement gains, focused instead on contextual learning and determined that students' conceptual understanding could be improved through language-based problem-solving tasks. School E was vague about the specific strategies they used to improve students' achievement and felt that continuing with their current strategies would produce the desired outcomes.

Through comparing the different approaches that each school took to improve student achievement, it appeared that the school with the highest achievement shifts focused least on testing and invested more time on teaching in context. Although it was not reported in the study that the School D teachers had referred to research or consulted external experts, they may have done so in the course of their inquiry cycle. Existing literature supports teaching maths contextually as it allows students to develop a deeper understanding of the usefulness and application of 'real' life, which is associated with higher achievement (Beswick, 2011). 
Table 3

Progress across Two Terms by School using Cliff's delta

\begin{tabular}{cccc}
\hline School & Addition/subtraction & Multiplication/division & Place value \\
\hline A & 0.22 & 0.23 & 0.36 \\
B & 0.17 & 0.23 & 0.32 \\
C & 0.11 & 0.44 & 0.25 \\
D & 0.35 & 0.49 & 0.45 \\
E & 0.31 & 0.1 & 0.15 \\
\hline
\end{tabular}

(Table reproduced from Ell \& Meissel, 2011, p. 181)

\section{Quasi-experimental or comparative inquiry research studies}

Some studies demonstrated the effectiveness of their inquiries by reporting the differences in achievement shifts/gains between students whose teachers had participated in the inquiry PD and non-participants (Bruce et al., 2010; Buczynski \& Hansen, 2010). Bruce et al. compared the achievement of students at schools in two districts whose teachers had participated in two different types of mathematics PD. District $A$ teachers engaged in collaborative professional learning groups, whereas District $B$ teachers were engaged in a large-scale PD model. The study demonstrated that students from District A whose teachers were in collaborative professional learning groups achieved at higher levels than students of teachers in District B.

Student achievement in mathematics was measured in six domains: content, problemsolving, reasoning, representation, communication, and connections. Although District B students had higher mathematics achievement across all except one of the domains in the pre-tests, with effect sizes that ranged from $d=-0.17$ to $d=-0.78$, District A students outperformed District $B$ in the post-tests. When the six mathematical process scores were combined into a single mean score for the pre-test and post-test, District A students demonstrated an overall improvement in mathematics, whereas District B students' performance stayed almost the same.

It appeared that differences in teacher practices between the districts might have contributed to the higher student achievement in District A. Teachers in District A benefitted from being engaged in collaborative inquiry, inquired into their students' learning needs, received support from expert teachers to change their practice, read research, and collaboratively planned and taught lessons together. Furthermore, they took more risks with their teaching than District B teachers and engaged their students in more problem-based and highly challenging learning tasks.

Buczynkski and Hansen (2010) also explored the impact on students' science achievement of teacher participation versus non-participation in an ILP in two school districts. Results showed that in District one, science test scores improved slightly over one year for students whose teachers participated in the ILP compared with non-ILP teachers' students. Nine percent of ILP participants' students scored 'proficient/advanced' in the second year of the study compared to $2 \%$ from non-ILP participants' students.

In District Two, there was no change in the proficiency scores for students of ILP teachers over one year (scores stayed at $30 \%$ ), but students of the non-ILP teachers showed a $4 \%$ loss in those students who achieved a 'proficient' score. Achievement gains were most significant at sites where several teachers participated in the ILP. The average gain district- 
wide was five percentage points, but in schools with multiple teachers participating in ILP, gains were as high as 15\% over one year (Buczynski \& Hansen, 2010).

\section{Associations between collaborative inquiry and student achievement}

Ronfeldt et al. (2015) investigated whether instructional team collaborations in 36 elementary and secondary schools in the USA predicted student achievement in mathematics and reading. Results revealed that teacher collaboration appeared to contribute to both student achievement and teacher improvement. Teacher collaboration related to student assessment appeared to be more predictive of student achievement than collaboration about instruction and students, but positive and significant effects were found for all collaboration types. Schools with teams who self-reported that they were engaged in better quality collaborations had higher achievement gains in both mathematics and reading. These results highlight the beneficial associations between teacher collaboration and achievement. However, results should be treated cautiously as the study design did not enable causal conclusions to be drawn.

\section{Inquiry research studies that reported achievement shifts without effect sizes}

Knight et al. (2008) researched a teacher inquiry in South Auckland primary schools with a focus on raising student achievement. After three years, the mean score of students who were present for all samples improved from a below-average band mean reading stanine (in the STAR test of reading) of 3.21 at the start of one school year to an average band mean reading stanine of 4.00 at the end of the following year. A stanine of 4.00 or above is average or above average. Data for writing indicated that a higher percentage of students were making maturational gains within a year. Longitudinal data showed that the median writing level within a year group cohort was improving at a higher rate than maturational gains.

The Quality Teaching, Research and Development Programme (QTR\&D; Earl et al., 2008) aimed to enhance learning for Māori and Pasifika students. In conjunction with tertiary institutions, teachers were supported to complete university courses and collaborative inquiry/action research projects related to improving the achievement/educational outcomes of their students.

The study reported that 53 teachers (who had collected qualitative, quantitative or a mix of both data types) reported improvements in learning outcomes or behaviours of their Māori or Pasifika students. A further 16 teachers reported that students' learning outcomes were mixed, and six reported no change in outcomes. Evidence was provided in the form of standardised tests, teacher-made assessments, reflections, or observed changes in student behaviour. However, effect sizes or examples of student achievement data pre- and postintervention were not reported. The inclusion of the quantitative data or the use of quotes to support the results section of the QTR\&D evaluation would have enhanced these findings.

Mykysey (2011) undertook an individual inquiry to improve the spelling and writing (in English) of six first-grade emergent bilingual students. During the inquiry, she implemented a range of process-writing instructional techniques with her students. Over six months, all students progressed in writing and spelling. In spelling, three students progressed from semiphonetic to conventional six months later; two students progressed from pre-communicative to transitional; and one student progressed from semi-phonetic to transitional. In writing, two students progressed from semi-phonetic to conventional six months later; two students progressed from pre-communicative at baseline to phonetic; one student progressed from precommunicative to transitional; and one progressed from semi-phonetic to transitional. 


\section{A discussion of the characteristics of effective teacher inquiry programmes}

Across the studies presented in this literature review and in the wider teacher inquiry field, researchers referred to a range of characteristics of effective programmes, which are discussed in the following sections. Most studies related 'effectiveness' to how well the steps and actions taken within an inquiry cycle were associated with positive achievement shifts for students. As reported earlier, teacher inquiry is usually a sub-set of a more extensive professional learning and development programme undertaken by teachers. Therefore, caution should be used when attributing improvements exclusively to the teacher inquiry itself.

\section{An unrelenting focus on raising student achievement}

Most critical to a worthwhile inquiry project were teaching practice changes, or the implementation of an intervention that focused on raising student achievement (Earl et al., 2008; Ell \& Meissel, 2011; Parr \& Timperley, 2010). Researchers have argued that the effectiveness of teacher inquiry and professional learning must be assessed on how well it improved students' educational outcomes (Timperley et al., 2009). Claims of improvement in educational outcomes, therefore, required testing and checking of data and other evidence to confirm whether the results were associated with changes to teaching.

\section{Effective inquiries are cyclical}

Primarily, effective inquiry programmes were cyclical rather than a one-off event or a list of items to be checked off. Earl et al. (2008) also cautioned that a single inquiry was unlikely to lead to sustained or long-term changes and that the power of inquiry came from it becoming an established way of doing things in a school or a "habit of mind" (pp. 11-12). A further advantage of cyclical, ongoing inquiries was that teachers had multiple opportunities to collect and analyse data which allowed them to evaluate the effectiveness of the inquiry to meet learning goals (Slavit, Nelson, \& Kennedy, 2010).

\section{Effective inquiries take time}

Generally, effective teacher inquiry projects allowed enough time for teachers to develop pedagogical knowledge about the learning problem or challenge they were investigating for data to be collected and analysed, and to make decisions about further actions and next steps. This is consistent with literature about effective teacher professional learning and development (Timperley et al., 2008). Some PLD studies reported that engagement in inquiry for at least one year was required to achieve significant outcomes for students (Timperley et al., 2009). Others reported that a minimum contact period of 14 hours engaged in collaboration or PLD was needed for positive effects (Yoon et al., 2007). However, programmes with 30 or more contact hours (Guskey \& Yoon, 2009) or 1-2 years had the most significant effect on student achievement outcomes (Alton-Lee, 2011). The studies in this review with positive shifts in student achievement were typically six months in duration or longer (Knight et al. 2008; Mykysey, 2011).

Kennedy's (1998) meta-analysis did not find a relationship between time spent on PD and improved student outcomes. In her study, some short workshop-style programmes led to positive outcomes for student achievement while a year-long programme demonstrated adverse effects. Logically, it appeared that a longer time spent on ineffectual practices or 
interventions did not increase their worth or lead to better student outcomes (Guskey \& Yoon, 2009). The general conclusion about time for teacher inquiries was that it enabled projects to achieve their goals and was expended usefully on relevant content, pedagogy, or both (Alton-Lee, 2011).

\section{Accessed external expertise}

A further factor associated with effective inquiries was the use of external expertise (Parr \& Timperley, 2010; Timperley et al., 2009). Due to the depth of content knowledge and skills required to make changes to teaching practices, Timperley et al. (2009) noted that most teachers' projects benefitted from help from external expertise. Equally, external research partners were able to critique and challenge teachers' problematic practices more readily than their colleagues or through self-reflection. The most practical examples of support occurred when external experts worked collaboratively with teachers and they were fully involved with the learning process, rather than when experts directed teachers to adopt their recommendations and changes (Buczynski \& Hansen, 2010). Data collection and analysis was an important area where teachers benefitted from the support of external partners with research expertise (Sinnema, Alansari, \& Turner, 2018).

\section{Teachers' engagement in the process}

A key characteristic of the teacher inquiry process is that teachers take a central role in investigating solutions to their own teaching or learning challenges (Mykysey, 2011). Existing research that explored the benefits of inquiry has indicated that teachers are more likely to implement changes to their practice when they have devised the solutions to their learning challenges (Luckin, Clark, Avramides, Hunter, \& Oliver, 2017; Slavit et al., 2010). Timperley et al. (2008) reported that teachers' engagement in professional learning was strongly related to the content taught and the activities provided, and determined whether teachers engaged sufficiently to obtain the level of knowledge and skills required that improved students' outcomes.

\section{Teacher collaboration}

Collaboration between teachers was identified as an important factor for teacher inquiries (Bruce et al., 2010; Butler \& Schnellert, 2012; Earl, Timperley, \& Stewart, 2008; Ronfeldt et al., 2015; Timperley et al., 2008). Although teachers often complete individual inquiries, they benefit from the discussions and exchange of ideas that take place in collaborative inquiry groups. Professional dialogue about others' inquiries allows teachers to reflect on their own projects and to identify where improvements could be made (Alagül \& Gürsel, 2019).

Some researchers have suggested that collaboration could be enhanced by ensuring that inquiry groups had commonalities (Ermeling, 2010; Henry \& Wilson, 2017), for example, by putting teachers in groups together who have similar inquiry goals, who taught in the same subject area or year level or were located near to each other. However, Fowler (2012) proposed reciprocal sharing of inquiries between teachers within and across curriculum areas, which suggested that teachers could benefit from others whose experience was dissimilar. 


\section{The participation and support of school leaders}

Teacher inquiries were successful when they were supported by principals and other school leaders who also participated in inquiries (Fowler, 2012; Timperley et al., 2008). Findings from the best evidence syntheses (Alton-Lee, 2011) also favoured school leaders' active support and commitment to teacher inquiry to improve student outcomes. School leaders had an essential role in creating the conditions for achievement-focused professional inquiry in schools by providing teachers with opportunities and time to collaborate and discuss their learning with others, and to allow them to apply what they had learnt with students (AltonLee, 2011; Slavit et al., 2010).

\section{Constraints and barriers to effective teacher inquiry}

This section of the review focuses on common challenges and difficulties that occurred in teacher inquiries. Challenges included barriers that prevented researchers from completing inquiries with positive outcomes for students (e.g., teachers did not change their practice) or factors where an inquiry did not demonstrate effectiveness (e.g., evidence of shifts in student achievement were not presented).

\section{Teachers' limited data literacy}

One common issue in teacher inquiry research was that teachers found analysis, interpretation, and use of student data to inform instruction challenging (Jacobs, Gregory, Hoppey, \& Yendol-Hoppey, 2009; Reeves, Summers, \& Grove, 2016; Sinnema et al., 2018). In the evaluation of the Teacher-led Innovation Fund (Sinnema et al., 2018), a governmentfunded programme where teachers take an inquiry approach to implement teaching and learning innovations in their schools, some project teams lacked the confidence and capability to collect quality data and complete useful analyses. Project reports often made vague claims unsupported by specific evidence or analyses. For example, "Overall, the inquiry ... has resulted in the uplifting of student achievement, particularly for our target students, and the teaching and learning of our teachers" (Sinnema et al., 2018, p. 12). From statements like this, it was not clear which students' achievement had improved, in what subjects, or by how much. Furthermore, data were not presented or analysed to support the claims of student success. Data literacy can be a barrier to evaluating intervention effects and can compromise the quality. If teachers cannot access or use data effectively, then they may not identify the most pressing and catalytic issues to focus their inquiry on in the first place.

\section{Lack of clarity about the impact of inquiry on student achievement}

Associated with the lack of data collected and analysed was a limited connection between the teacher inquiry and student achievement outcomes (Butler \& Schnellert, 2012). Furthermore, student achievement was often only descriptively reported, without evidence that quantified gains or shifts. Equally, some inquiries focused on shifts in teacher practice and learning, and not on the impact of the inquiry on students' educational outcomes. For example, Butler and Schnellert's (2012) study predominantly referred to teachers' engagement and associated shifts in teachers' learning and practice and only made a vague reference to students' outcomes. The authors noted that the inquiry might have the "potential to achieve valued outcomes for students" (p. 1215). 
Similarly, Limbrick, Kirton, Knight, Funaki, and Evans (2004) found that their teacher inquiry had the potential to increase student achievement outcomes. Their inquiry with teachers in a South Auckland school cluster had a goal of increasing student achievement and progress in writing. The inquiry used baseline student achievement data to develop teaching strategies focused on raising the achievement of Māori and Pasifika students, and boys. Teachers were supported with data analysis and interpretation to increase their data capability, and their professional learning focused on developing pedagogical and content knowledge in the teaching of writing. Unfortunately, the authors did not report increases in student achievement. They were hopeful, however, that teachers' increased pedagogical and content knowledge of writing would lead to improved student achievement outcomes in the future. Including achievement data in inquiry research studies has a dual purpose of informing readers and researchers of the outcomes for students, but also guides future researchers about the types of data and evidence that are useful for assessing an effective inquiry project.

\section{Teachers' changes to their practice were insufficient}

In their review of teacher professional learning, Timperley and Alton-Lee (2008) found that providing teachers with professional learning did not necessarily lead to improved outcomes for learners. The lack of positive effects for students was attributed to not confronting teachers' stereotypes or prejudices, and the limited progression of teacher knowledge and practice.

Existing research has shown that even when teachers are provided with solutions to their students' learning issues, not all teachers will fully engage in implementing new practices (McLaughlin \& Talbert, 1993; Timperley et al., 2008). Some teachers wholly ignored or rejected new ideas, made no changes to their practice, kept teaching in the same way, and blamed their students for not learning (McLaughlin \& Talbert, 1993; Timperley et al., 2008). Other teachers continued teaching in the same way but thought they were doing something different, or only selected some aspects of a new practice and applied it to what they were currently doing (Timperley et al., 2008).

Some groups of teachers lowered their expectations for student achievement as a result of professional learning, taught less content, and thought a low-pressure approach would benefit students. Again, students were blamed for not learning. A final group of teachers recognised there was a mismatch between students' poor performance and their current teaching methods and found new ways to teach that worked for their students (McLaughlin \& Talbert, 1993; Timperley et al., 2008). For some teachers, this involved making substantial modifications to their practice (Timperley et al., 2008).

A danger in teacher inquiry is when teachers do not interrogate how their teaching practices and beliefs have contributed to student problems. For example, data nationally show that Māori students have a lower pass rate than other students in the NCEA English achievement standard, AS91100, which assesses students' ability to read and analyse unfamiliar texts. However, teachers may respond to similar data in their own school by enrolling students in alternative standards rather than by changing their teaching. There is a risk, therefore, that inquiry can reinforce stereotypes and essentialise deficits (Wilson, Madjar, \& McNaughton, 2016). 


\section{Conclusion}

The purpose of this literature review was to investigate the impact of teacher inquiry on student achievement in studies published since 2008. A synthesis of the characteristics of more and less effective inquiry was also identified. Key characteristics of effective inquiry were a focus on student achievement, sufficient investment of time, teacher engagement and collaboration, external expertise, and school leaders' support. Many studies have been published in the teacher inquiry field during the last decade, but few were evidence-based research that focused on raising student achievement. Although some reported improved student achievement, findings were often descriptive, and data were not collected or presented to support claims (Curcic, Lapat, Susec, \& Ignac, 2018). Other teacher-inquiry studies reported benefits for student learning (Simpson, 2017) or teacher practice (Charteris \& Thomas, 2017), but not achievement shifts.

A possible limitation of this literature review was its explicit focus on studies that showed an evidence-based association between the teacher inquiry and student achievement shifts. Teacher inquiry is a broad research field, and future research could focus on how inquiry impacts a broader range of student outcomes.

A further research gap was that most studies included teacher inquiry as a component of professional learning, but few looked at inquiry by itself. The interconnection between inquiry and professional learning has made it difficult to establish whether the inquiry was the contributing factor to improving student achievement, whether it was professional learning, or something else. A focus for future research could be closer interrogation of the aspects of teacher inquiry that contribute directly to improved student achievement.

This review has implications for teachers' and school leaders' future inquiry research through the identification of characteristics associated with successful inquiries. The lack of published studies focused on student achievement highlights the need for greater data interrogation and to identify teaching practice changes that will lead to improved student outcomes. Furthermore, recent changes to education policy (Ministry of Education, 2019) that removed the requirement for teachers to undertake inquiries for appraisal purposes have the potential to change how teachers and leaders approach, design, and undertake their inquiries. The importance of school leader involvement was also highlighted in this review. Leader support involves not only participating and taking an interest in teacher research but also guiding teachers towards inquiries with an achievement-related focus.

This review aimed to provide an overall picture of the teacher inquiry research studies that focused on raising student achievement, but there was a paucity of evidence-based studies with this emphasis. Improving student learning and raising student achievement is theorised as a critical aspect of effective teacher inquiry (Timperley et al., 2009) and PLD generally. Consequently, for conclusions to be made about the advantages of teacher inquiry for student achievement, a greater number of studies that show an association between inquiry and increased student outcomes is needed. 


\section{References}

Aitken, G., \& Sinnema, C. (2008). Effective pedagogy in social sciences/tikanga ā iwi: Best evidence synthesis iteration. Wellington: Ministry of Education.

Alagül, Ö., \& Gürsel, F. (2019). Teacher who (cannot) change: Experimental processes of physical education teachers by means of pedagogical innovations at the time of their professional development. Education and Science, 44, 401-420. doi.10.15390/EB.2019.8016

Alton-Lee, A. (2011). (Using) evidence for educational improvement. Cambridge Journal of Education, 41, 303-329. doi.org/10.1080/0305764X.2011.607150

Becker, L. A. (2000). Effect size (ES). Colorado Springs: University of Colorado. Retrieved from https://www.uv.es/ friasnav/EffectSizeBecker.pdf

Beswick, K. (2011). Putting context in context: An examination of the evidence for the benefits of 'contextualised' tasks. International Journal of Science and Mathematics Education, 9, 367-390. doi.10.1007/s10763-010-9270-z.

Bruce, C. D., Esmonde, I., Ross, J., Dookie, L., \& Beatty, R. (2010). The effects of sustained classroom-embedded teacher professional learning on teacher efficacy and related student achievement. Teaching and Teacher Education, 26, 1598-1608. doi.10.1016/j.tate.2010.06.011

Buczynski, S., \& Hansen, C. B. (2010). Impact of professional development on teacher practice: Uncovering connections. Teaching and Teacher Education, 26, 599-607. doi.10.1016/j.tate.2009.09.006

Butler, D. L., \& Schnellert, L. (2012). Collaborative inquiry in teacher professional development. Teaching and Teacher Education, 28, 1206-1220. doi.10.1016/j.tate.2012.07.009

Charteris, J., \& Thomas, E. (2017). Uncovering 'unwelcome truths' through student voice: Teacher inquiry into agency and student assessment literacy. Teaching Education, 28, 162-177. doi.10.1080/10476210.2017.1331213

Cochran-Smith, M., \& Lytle, S. L. (1999). The teacher research movement: A decade later. Educational Researcher, 28, 15-25. doi.org/10.3102/0013189X028007015

Corey, S. M. (1954). Action research in education. The Journal of Educational Research, 47, 375-380.

Curcic, S., Lapat, G., Susec, B., \& Ignac, B. (2018). From past aspirations to present achievements: A case study of three K-8 schools successfully educating Roma students. International Journal of Multicultural Education, 20, 24-41. doi.org/10.18251/ijme.v20i2.1638.

Donovan, M. S., Bransford, J. D., \& Pellegrino, J. W. E. (1999). How people learn: Bridging research and practice (030918584X). Washington, DC: National Academy Press.

Earl, L. M., Timperley, H., \& Stewart, G. M. (2008). Learning from the QTR \& D Programme: Findings of the external evaluation. Toronto, ON: Aporia.

Ell, F., \& Meissel, K. (2011). Working collaboratively to improve the learning and teaching of mathematics in a rural New Zealand community. Mathematics Education Research Journal, 23, 169-187. doi.10.1007/s13394-011-0010-7

Ermeling, B. (2010). Tracing the effects of teacher inquiry on classroom practice. Teaching and Teacher Education, 26, 377-388. doi.org/10.1016/j.tate.2009.02.019

Fowler, M. (2012). Leading inquiry at a teacher level: It's all about mentorship. Set: Research Information for Teachers, 3, 2-7. 
Gersten, R., Dimino, J., Jayanthi, M., Kim, J. S., \& Santoro, L. E. (2010). Teacher study group: Impact of the professional development model on reading instruction and student outcomes in first-grade classrooms. American Educational Research Journal, 47, 694-739. doi.10.3102/0002831209361208

Guskey, T. R., \& Yoon, K. S. (2009). What works in professional development? Phi Delta Kappan, 90, 495-500.

Henry, K., \& Wilson, A. (2017). Features of success: A study of an effective teaching community. In R. Jesson, A. Wilson, S. McNaughton, \& L. Mei (Eds.), Teachers leading inquiry for school problem solving (pp. 73-76). Wellington, New Zealand: NZCER Press.

Jacobs, J., Gregory, A., Hoppey, D., \& Yendol-Hoppey, D. (2009). Data literacy: Understanding teachers' data use in a context of accountability and response to intervention. Action in Teacher Education, 31, 41-55. doi.org/10.1080/01626620.2009.10463527

Kennedy, M. (1998). Form and substance in inservice teacher education. Madison, WI: National Institute for Science Education, University of Wisconsin.

Knight, N., Kirton, N., \& McCaulay, S. (2008, January). Developing partnerships for improving student outcomes. Paper presented at the International Congress for Schooling Effectiveness and Improvement Conference, Auckland, NZ.

Lerman, S., \& Zehetmeier, S. (2008). Face-to-face communities and networks of practising mathematics teachers. International Handbook of Mathematics Teacher Education, 3, 133-153. doi.org/10.1163/9789087905491_008

Limbrick, L., Buchanan, P., Goodwin, M., \& Schwarcz, H. (2010). Doing things differently: The outcomes of teachers researching their own practice in teaching writing. Canadian Journal of Education, 33, 897-924.

Limbrick, L., Kirton, N., Knight, N., Funaki, A., \& Evans, J. (2004, November). Teachers learning from student achievement data in writing. Paper presented at the National Conference of the New Zealand Association for Research in Education, Wellington.

Limbrick, L., \& Knight, N. (2005). Close reading of students' writing: What teachers learn about writing. English Teaching: Practice \& Critique, 4, 5-22. Retrieved from http://education.waikato.ac.nz/research/files/etpc/2004v4n2art1.pdf

Luckin, R., Clark, W., Avramides, K., Hunter, J., \& Oliver, M. (2017). Using teacher inquiry to support technology-enhanced formative assessment: A review of the literature to inform a new method. Interactive Learning Environments, 25, 85-97. doi.10.1080/10494820.2015.1121152

McLaughlin, M. W., \& Talbert, J. E. (1993). Contexts that matter for teaching and learning: Strategic opportunities for meeting the nation's educational goals. California, USA: Center for Research on the Context of Secondary Teaching, Stanford University.

Ministry of Education. (2007). The New Zealand curriculum. Wellington, NZ: Learning Media for the Ministry of Education.

Ministry of Education. (2019, 14 June). Collective agreement offers for primary teachers and principals, secondary teachers and area school teachers. Retrieved from http://www.education.govt.nz/news/collective-bargaining-fact-sheet-13-june-2019/

Mykysey, N. (2011). Gaining appreciation and understanding for writing in English in a bilingual class. Journal of Multilingual Education Research, 2, 102-116. 
Nichol, C., Chow, A., \& Furtwengler, S. (2018). Year-long teacher professional development on fifth grade student science outcomes. International Journal of Science Education, 40, 2099-2117. Retrieved from https://doi.org/10.1080/09500693.2018.1521027

Nolen, A. L., \& Putten, J. V. (2007). Action research in education: Addressing gaps in ethical principles and practices. Educational Researcher, 36, 401-407. doi.org/10.3102/0013189x07309629

Parr, J. M., \& Timperley, H. (2010). Multiple 'black boxes': Inquiry into learning within a professional development project. Improving Schools, 13, 158-171. doi.10.1177/1365480210375349

Reeves, T. D., Summers, K. H., \& Grove, E. (2016). Examining the landscape of teacher learning for data use: The case of Illinois. Cogent Education, 3(1), 1-21. doi.10.1111/bjet.12233

Ronfeldt, M., Farmer, S. O., McQueen, K., \& Grissom, J. (2015). Teacher collaboration in instructional teams and student achievement. American Educational Research Journal, 52, 475-514. doi.10.3102/0002831215585562

See, B. H., Gorard, S., \& Siddiqui, N. (2016). Teachers' use of research evidence in practice: A pilot study of feedback to enhance learning. Educational Research, 58, 56-72. doi.org/10.1080/00131881.2015.1117798

Simpson, A. (2017). Teachers negotiating professional agency through literature-based assessment. Literacy, 51, 111-119. doi.org/10.1111/lit.12114

Sinnema, C., Alansari, M., \& Turner, H. (2018). The promise of improvement through and of the teacher led innovation fund: Evaluation of the teacher-led innovation fund: Final report. Auckland, New Zealand: Auckland UniServices Limited.Retrieved from https://www.educationcounts.govt.nz/_data/assets/pdf_file/0005/184370/Teache r-Led-Innovation-Fund-Final-Report.pdf

Slavit, D., Nelson, T. H., \& Kennedy, A. (2010). Laser focus on content strengthens teacher teams. Journal of Staff Development, 31, 18-22.

Timperley, H., \& Alton-Lee, A. (2008). Reframing teacher professional learning: An alternative policy approach to strengthening valued outcomes for diverse learners. Review of Research in Education, 32, 328-369. doi.10.3102/0091732X07308968

Timperley, H., Parr, J., \& Bertanees, C. (2009). Promoting professional inquiry for improved outcomes for students in New Zealand. Professional Development in Education, 35(2), 227-245. doi.10.1080/13674580802550094

Timperley, H., Wilson, A., Barrar, H., \& Fung, I. (2008). Teacher professional learning and development: Best evidence synthesis iteration (BES). Wellington, NZ: Ministry of Education.

Wilson, A., Madjar, I., \& McNaughton, S. (2016). Opportunity to learn about disciplinary literacy in senior secondary English classrooms in New Zealand. The Curriculum Journal, 27, 204-228. doi.10.1080/09585176.2015.1134339

Yoon, K. S., Duncan, T., Lee, S. W.-Y., Scarloss, B., \& Shapley, K. L. (2007). Reviewing the evidence on how teacher professional development affects student achievement: Issues \& answers. REL 2007-No. 033. Washington, DC: National Center for Education Evaluation and Regional Assistance, Institute of Education Sciences, U.S. Department of Education. Retrieved from http://ies.ed.gov/ncee/edlab 
Dr Hana Turner-Adams (Ngāti Ranginui; Ngāi Tamarāwaho) is a research fellow in the Woolf Fisher Research Centre at the University of Auckland and a member of The Manaiakalani Programme research team. Her main research interests are Māori student success, teacher expectations, student-teacher relationships, and how to reduce disparities in educational achievement between Māori and non-Māori students. Her PhD research focused on the schooling experiences of high achieving Māori and non-Māori senior secondary school students, and the factors that contributed to their academic success.

Email: hana.turner-adams@aut.ac.nz

ORCID: $\underline{\text { http://orcid.org/0000-0003-1500-6504 }}$

Dr Aaron Wilson is Associate Dean (Research) for the Faculty of Education and Social Work, a senior literacy lecturer in the School of Curriculum and Pedagogy, and an Associate Director of the Woolf Fisher Research Centre at the University of Auckland. His research interests are in interventions to address disparities in education, disciplinary literacy teaching in secondary schools, subject English, learning in digital learning environments and teacher professional development. With Rebecca Jesson, Aaron is co-principal investigator for The Manaiakalani Programme. Aaron's teaching includes a post-graduate course in teaching as inquiry and inquiry is at the heart of all the research and development work he engages in.

Email: aj.wilson@auckland.ac.nz

ORCID: http://orcid.org/0000-0002-4593-2288

Dr Rebecca Jesson is the Associate Head of School (Research) in the School of Curriculum and Pedagogy, and Associate Director of the Woolf Fisher Research Centre in the Faculty of Education and Social Work at the University of Auckland. With Aaron Wilson, Rebecca is coprincipal investigator for The Manaiakalani Programme. Rebecca's research is situated in schools and their communities in New Zealand and the Pacific. Her focus is on designing with teachers' innovations that will improve the literacy outcomes for students.

Email: r.jesson@auckland.ac.nz

ORCID: http://orcid.org/0000-0003-4673-9655 